\title{
Effect of Triton X-100 on the Spectrophotometric Determination of Aluminium in the Presence of Iron(III) - Application to Various Water Samples
}

\author{
Bassima A. Abed Al-Hadi \\ Department of Chemistry/ College of Science/ University of Mosul
}

(Received 16/1/2018; Accepted 17/9/2018)

\begin{abstract}
An accurate simple, rapid and direct spectrophotometric method for the determination of aluminium in presence of iron (III) was developed. The method is based on the reaction of aluminium (III) with xylenol orange at $\mathrm{pH} 4.3$ using potassium hydrogen phthalate buffer solution to form a stable orange-red coloured complex which has maximum absorption at $512 \mathrm{~nm}$. This study is showing the effect of triton X-100 on the spectrophotometric determination of aluminium which effected the stability, limits of Beer's law, blanck value and final absorption spectrum. Beer's law was obeyed over the range of (1-200) $\mu \mathrm{g} / 25 \mathrm{ml}$ (i.e 0.04-8.0 ppm). The molar absorptivity and Sandell's sensitivity of the coloured complex are $1.173 \times 10^{4} 1 . \mathrm{mol}^{-1} . \mathrm{cm}^{-1}, 0.00230 \mu \mathrm{g} . \mathrm{cm}^{-2}$ respectively. The interference caused by iron (III) was suppressed by adding sodium cyanide as masking agent. The method has been applied successfully for determining aluminium (III) in various water samples.

The same work was done for the spectrophotometric determination of aluminium in the absences of triton X-100. While the analytical parameters recorded are $1.045 \times 10^{4} 1 . \mathrm{mol}^{-1} . \mathrm{cm}^{-1}$, $0.00258 \mu \mathrm{g} . \mathrm{cm}^{-2}$, the molar absorptivity and Sandell's sensitivity of the coloured complex respectively, and limits of Beer's law are (5-100) $\mu \mathrm{g} / 25 \mathrm{ml}$ (i.e. $0.2-4.0 \mathrm{ppm}$ ).
\end{abstract}

Keywords: Aluminium(III), Xylenol Orange, Triton X-100, Spectrophotometric.

\section{تأثير الـ ـ ( Triton X-100) عل القدير الليفي للألمونيوم بوجود الحيد (III) - النلبق عل iماذج مائية مختلفة

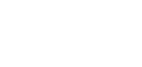

مُ قطويرطريقةطيفية بسطة وسريعة ومبلثرة لنقدير الألمنيوم بوجود الحيد (III) حيث تعتمد هذه الطريقة على تفاعل

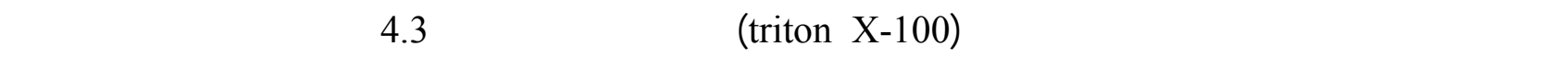

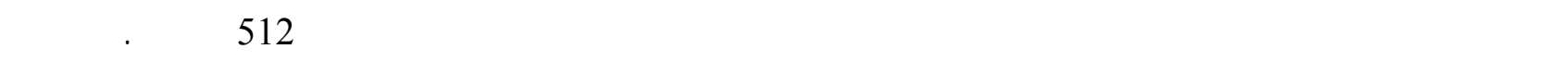
هذه الدرلسة تأثير ال ـ (triton X-100) على القدير الطيفي للألمنيوم وتأثيره على لسنقرارية المعقد المتكون وحدود قاون بير وقيم لمتصاص المحلول الصوري والطف النهائي للمعقد المتكون. كانت حدود قانون بير ضمن المدى (1 -200) ميكروغرلأ/

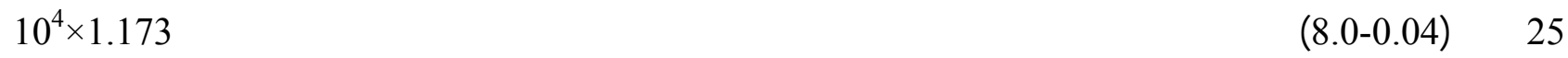

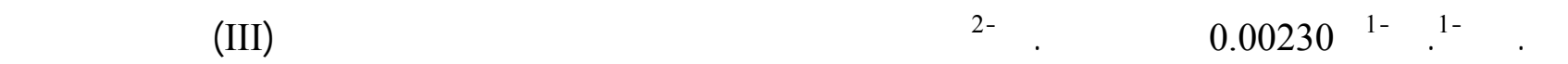
الصويوم كعلمل حجب وم ظبيق الطريقة بنجاح لقدير الألمنيوم في نماذج مائية مختلفة. قم درلسة تأثير غيلب ال ـ (triton X-100) على تقدير الألمنيوم بلستخدلم الطريقة المقترحة حيث كانت القيم التحليلية

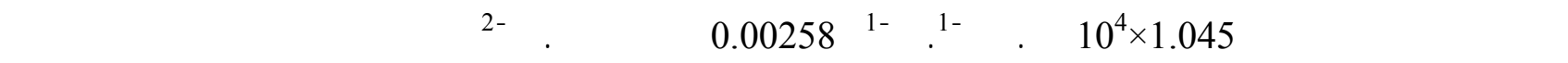
ساندل للحسلسية على التوالم، لما حدود قانون بير فقد كانت (5 -100) ميكروغراd/ 25 مل، (0.2-4.0) جزء لكل مليون. الهاملت الدالة: الالمنيوم، الزايلينول البرتقالي، triton X-100، ققدير مطيفي. 


\section{INTRODUCTION}

Aluminium is a silvery white member of the boron group of chemical elements. It is not soluble in water under normal circumstances. Aluminium is the third most abundant element in the earth's crust (Meija et al., 2016). Aluminium forms strong chemical bonds with oxygen, compared to most other metals. Structural components made from aluminium and its alloys are vital to the aerospace industry and are important in other areas of transportation and structural materials. The most useful compounds of aluminium, at least on a weight basis, are the oxides and sulfates (Devoret and Schoelkopf, 2013).

Aluminium is remarkably nontoxic, the health effects of aluminium are of interest in view of the widespread occurrence of the element in the environment and in commerce. Human exposure to aluminium. The human population is exposed to aluminium (Al) from diet, antacids and vaccine adjuvants, but frequent application of Al-based salts to the underarm as antiperspirant adds a high additional exposure directly to the local area of the human breast (Exley, 2013). Al has been measured in human breast tissues/fluids at higher levels than in blood, Al can adversely impact on human breast epithelial cell biology (Darbre, 2016). Aluminium's free metal cation, Alaq3+, is highly biologically reactive. Biologically reactive aluminium is present throughout the human body and while, rarely, it can be acutely toxic, much less is understood about chronic aluminium intoxication. Alzheimer's disease is a symptom of chronic aluminium intoxication over decades (Exley, 2016). Aluminum has been shown by independent researchers to be particularly genotoxic to the genetic apparatus, and it has become reasonably clear that aluminum disturbs genetic signaling programs in the CNS that bear a surprising resemblance to those observed in Alzheimer's disease (AD) brain. (Pogue and Lukiw, 2016)

Several Spectrophotometric methods have been used for the determination of aluminium, some of these methods have used different kinds of reagent such as alizarin red S (Eder et al., 2015), Eriochrome Cyanine R (Siriangkhawut et al., 2013), 5-Bromo-2-hydroxy-3methoxybenzaldehyde-p-hydroxybenzoic hydrazone, (Saritha and Reddy 2014), 2hydroxynaphthaldehydebenzoylhydrazone (Jamaluddin et al., 2010), 8-hydroxyquinoline (Santarossa et al., 2016), (Panhwar et al., 2018), N-((2-hydroxy-naphthalen-1-yl)methylene) acetylhydrazide (Al-Kindy et al., 2015), Chrome Azurol S (Ni et al., 2007) and (Shishov et al., 2014). A flow injection have been used for the determination of aluminium with Eriochrome cyanine R (Khanhuathon et al., 2015), other method used schiff base (Rana et al., 2017), A flame atomic absorption spectrometry also used for the determination of aluminum with xylidyl blue and Triton X-114 (Ulusoy et al., 2011), and reverse-phase high-performance liquid chromatography using a fluorescence detector have been used for determined of aluminium (Heena et al., 2015), also the elimination of iron interference in the molecular spectrophotometric determination of aluminum (Andrade et al., 2008), other methods using the H-point standard addition method (Kobra et al., 2007), the complexes with xylenol orange (XO) is presented for the rapid determination of aluminium (Carpani et al., 2004).

Xylenol orange also known as 3,3'-Bis [N,N-bis(carboxymethyl)aminomethyl]-ocresolsulfonephthalein tetra sodium salt is an organic reagent, most commonly used as a tetrasodium salt as an indicator for metal titrations (Marczenko, 2000).

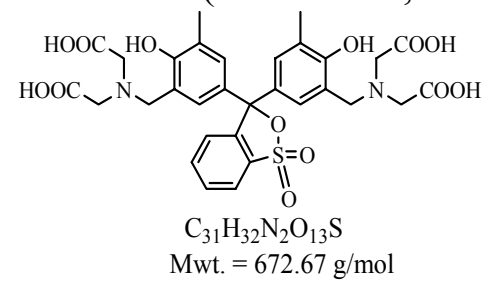

The proposed work aims mainly to develop a sensitive spectrophotometric method for the determination of aluminium in various water samples via xylenol orange dye. Also this work study the effect of presence and absence of triton X-100 on the determination of aluminium and eliminated the interference caused by iron(III). 


\section{EXPERIMENTAL}

\section{Apparatus}

The absorption spectra and absorbance measurements were recorded on a double-beam Shimadzu UV-Visible recording spectrophotometer UV-160 with $1.0 \mathrm{~cm}$ matched plastic cells. $\mathrm{pH}$ measurements were performed using HANNA instrument $\mathrm{pH} 211$ microprocesser $\mathrm{pH}$ meter.

\section{Reagents}

All chemicals used were of analytical reagent grade.

Stock aluminium (III) solution $100 \mu \mathrm{g} / \mathrm{ml}$ : This solution was prepared by dissolving $0.1391 \mathrm{~g}$ of hydrated aluminum nitrate $\mathrm{Al}\left(\mathrm{NO}_{3}\right)_{3} \cdot 9 \mathrm{H}_{2} \mathrm{O}$ (Fluka) in distilled water and the volume was completed to the mark with distilled water in a $100 \mathrm{ml}$ volumetric flask. Working solution $5 \mu \mathrm{g} / \mathrm{ml}$ solution of aluminum (III) was prepared by appropriate dilution of the stock solution with distilled water.

Triton X-100 solution (1\%): This solution was prepared by dissolving $1 \mathrm{~g}$ of triton X-100 (Fluka) in distilled water and the volume was completed to the mark in a $100 \mathrm{ml}$ volumetric flask with distilled water.

Xylenol orange solution $\left(1 \times \mathbf{1 0}^{-3} \mathbf{M}\right)$ : This solution was prepared by dissolving $0.1681 \mathrm{~g}$ of chromogenic reagent xylenol orange (Fluka) in distilled water, then complete the volume with distilled water to the mark in a $250 \mathrm{ml}$ volumetric flask. The solution was then transferred to a dark bottle it was stable for at least one week.

Buffer solution (pH 4.3): This solution was prepared by mixing $50 \mathrm{ml}$ of $0.1 \mathrm{M}$ potassium hydrogen phthalate and $4.7 \mathrm{ml}$ of $0.1 \mathrm{M}$ sodium hydroxide and the volume is diluted to the mark, with distilled water, in a $100 \mathrm{ml}$ volumetric flask (Perrin and Dempsey, 1974).

Sodium cyanide solution (0.01M): This solution was prepared by dissolving $0.1225 \mathrm{~g}$ of sodium cyanide in distilled water then the $\mathrm{pH}$ of the solution was then brought to 4.3 , the volume was completed to the mark with distilled water in a $250 \mathrm{ml}$ volumetric flask.

\section{Procedure and calibration graph}

Aliquots of standard solution 1-200 $\mu \mathrm{g}$ of aluminium was transferred into a series of $25 \mathrm{ml}$ volumetric flask. To each flask, $3 \mathrm{ml}$ of $\mathrm{KH}$-phthalate buffer solution, $2 \mathrm{ml}$ of triton X-100 (1\%) and $2 \mathrm{ml}$ of xylenol orange $1 \times 10^{-3} \mathrm{M}$ were added. The reaction mixture were diluted to the mark with distilled water and mixed well. The absorbance of the produced coloured complex was measured at $512 \mathrm{~nm}$ against the corresponding reagent blank. A linear calibration graph (Fig.1) is obtained over the range (i.e $0.04-8.0 \mathrm{ppm}$ ) with a molar absorptivity $1.173 \times 10^{4} 1 . \mathrm{mol}^{-1} \cdot \mathrm{cm}^{-1}$ and sandell $0.00230 \mu \mathrm{g} . \mathrm{cm}^{-2}$ in presence of triton X-100.

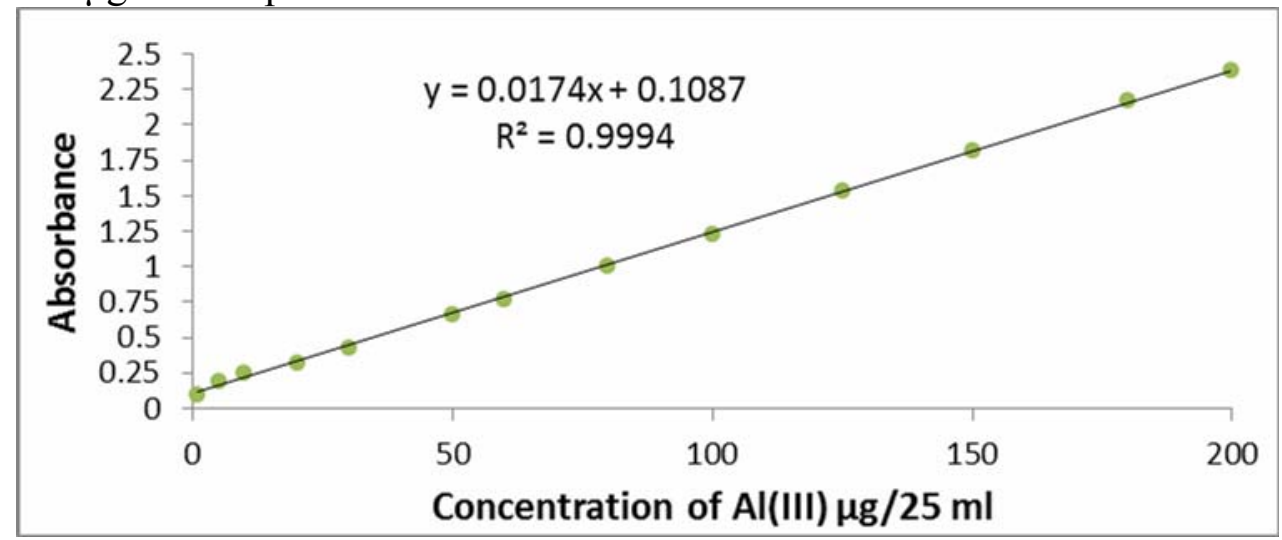

Fig. 1: Calibration graph of aluminium in presence of triton $\mathrm{X}-100$

\section{RESULT AND DISCUSSION}

Aluminium is complexed with xylenol orange in presence of triton $\mathrm{X}-100$ at $\mathrm{pH} 4.3$ of potassium hydrogen phthalate buffer solution, which form an intensely-coloured complex that shows an absorption maxima at $512 \mathrm{~nm}$ against reagent blank solution. This work explain the effect of triton X-100 on the determination of aluminium. 


\section{Study of the optimum experimental conditions}

For the following investigations, $5 \mu \mathrm{g}$ of aluminium is taken in $25 \mathrm{ml}$ volumes.

\section{Effect of pH}

The effect of $\mathrm{pH}$ on the intensity of coloured complex is studied by adding different amounts (0.1-1.0) $\mathrm{ml}$ of $0.001 \mathrm{M}$ from (sulphuric acid, hydrochloric acid, nitric acid, acetic acid) and (0.1-2.0) $\mathrm{ml}$ of sodium hydroxide solutions to an aliquot of solution containing $5 \mu \mathrm{g}$ of aluminium. The intensity of absorption were measured against the reagent blank. The results are shown in (Table 1 and 2) were carried out in case of absence of triton X-100:

Table 1: Effect of different kinds and amounts of acids

\begin{tabular}{|c|c|c|c|c|c|c|c|}
\hline \multirow{2}{*}{$\begin{array}{c}\text { Kind of acid } \\
(0.001) M\end{array}$} & \multicolumn{5}{|c|}{ Absorbance/ $\mathrm{ml}$ of acid } & \multirow[b]{2}{*}{$\lambda_{\max }$} & \multirow{2}{*}{ Final $\mathrm{pH}$} \\
\hline & 0.1 & 0.3 & 0.5 & 0.7 & 1.0 & & \\
\hline Sulphuric acid & 0.170 & 0.153 & 0.110 & 0.093 & 0.046 & 512 & $2.80-3.63$ \\
\hline Hydrochloric acid & 0.144 & 0.121 & 0.108 & 0.087 & 0.053 & 511 & $2.61-3.58$ \\
\hline Nitric acid & 0.099 & 0.083 & 0.065 & 0.043 & 0.028 & 510 & $2.70-3.52$ \\
\hline Acetic acid & 0.118 & 0.094 & 0.071 & 0.048 & 0.039 & 512 & $2.57-3.84$ \\
\hline Without acid & \multicolumn{5}{|c|}{0.194} & 512 & 4.31 \\
\hline
\end{tabular}

Table 2: Effect of $0.001 \mathrm{M}$ sodium hydroxide

\begin{tabular}{|c|c|c|c|}
\hline ml of NaOH (0.001) M & Absorbance & $\boldsymbol{\lambda}_{\max }$ & Final pH \\
\hline 0.1 & 0.128 & 499 & 4.68 \\
\hline 0.3 & 0.091 & 496 & 4.92 \\
\hline 0.5 & 0.088 & 501 & 5.16 \\
\hline 0.7 & 0.064 & 503 & 5.54 \\
\hline 1.0 & 0.046 & 499.5 & 5.21 \\
\hline 2.0 & 0.020 & 501 & 6.71 \\
\hline Without base & 0.194 & 512 & 4.31 \\
\hline
\end{tabular}

The results in (Table 1 and 2) indicated that the addition of acid or base gave no useful effect. Therefore, the use of acid or base was omitted in the subsequent experiments. Several buffers (Purrin and Dempsey, 1974) of $\mathrm{pH} 4.3$ were prepared and their effects on using different amounts were studied. The results were summarized in (Table 3 ).

Table 3: Effect of buffer solutions

\begin{tabular}{|c|c|c|c|c|c|}
\hline \multirow{2}{*}{$\begin{array}{c}\text { ml of } \\
\text { buffer sol } \\
\text { ution }\end{array}$} & $\begin{array}{c}\text { Citric acid- } \\
\text { NaOH }\end{array}$ & Tartaric acid- NaOH & $\begin{array}{c}\text { KH-phthalate- } \\
\text { NaOH }\end{array}$ & $\begin{array}{c}\text { Succinic acid- } \\
\text { NaOH }\end{array}$ & $\begin{array}{c}\text { Citric acid-sodium } \\
\text { citrate }\end{array}$ \\
\cline { 2 - 6 } & 0.112 & 0.130 & 0.191 & 0.143 & 0.081 \\
\hline 1 & 0.096 & 0.124 & 0.199 & 0.131 & 0.073 \\
\hline 3 & 0.088 & 0.110 & 0.204 & 0.128 & 0.066 \\
\hline 4 & 0.073 & 0.092 & 0.201 & 0.119 & 0.050 \\
\hline 5 & 0.052 & 0.062 & 0.195 & 0.100 & 0.038 \\
\hline Final pH & $3.82-4.61$ & $3.29-4.31$ & $3.87-4.64$ & $3.56-4.43$ & $3.47-4.52$ \\
\hline
\end{tabular}

*Measured at $\lambda=512 \mathrm{~nm}$, Absorbance without buffer solution $=0.193$.

The results in (Table 3) indicate that $3 \mathrm{ml}$ of $\mathrm{KH}$-phthalate- $\mathrm{NaOH}$ buffer gives maximum absorbance, and enhances the stability of the product hence, it is selected for the subsequent experiments.

\section{Effect of reagent amount}

The effect of different amounts of $1 \times 10^{-3} \mathrm{M}$ xylenol orange were added to the different amounts of aluminium (III) in two set of volumetric flasks, while other conditions being kept constant was studied. $1 \mathrm{ml}$ of the reagent solution has been found to be optimum volume without using triton $\mathrm{X}-100$, but $2 \mathrm{ml}$ of the reagent solution has been found to be optimum volume in 
presence of triton X-100 since the linearity (correlation coefficient) is good, and this amount of the reagent gives lower value of reagent blank as shown in (Table 4).

Table 4: Effect of reagent amount

\begin{tabular}{|c|c|c|c|c|c|c|c|c|c|}
\hline \multirow{2}{*}{$\begin{array}{c}\text { ml of } 1 \times 10^{-3} \mathrm{M} \\
\text { xylenol orange } \\
\text { solution }\end{array}$} & \multicolumn{9}{|c|}{ Absorbance / $\mu \mathrm{g}$ of $\mathrm{Al}^{+3}$ in $25 \mathrm{ml}$ (in the absence of triton $\mathrm{X}-100$ ) } \\
\hline & 3 & 5 & 15 & 30 & 50 & 70 & 100 & $\mathbf{r}^{2}$ & Blank \\
\hline 0.5 & 0.051 & 0.093 & 0.211 & 0.366 & 0.411 & 0.652 & 0.633 & 0.977479257 & 0.052 \\
\hline 1.0 & 0.101 & 0.181 & 0.401 & 0.691 & 0.964 & 1.279 & 1.548 & 0.999391782 & 0.089 \\
\hline 1.5 & 0.097 & 0.165 & 0.291 & 0.573 & 0.812 & 1.188 & 1.402 & 0.997091837 & 0.103 \\
\hline \multicolumn{10}{|c|}{ Absorbance / $\mu \mathrm{g}$ of $\mathrm{Al}^{+3}$ in $25 \mathrm{ml}$ (in the presence of $2 \mathrm{ml}$ of $1 \%$ triton $\mathrm{X}-100$ ) } \\
\hline & 3 & 5 & 25 & 50 & 100 & 150 & 200 & $r^{2}$ & Blank \\
\hline 1.5 & 0.073 & 0.183 & 0.322 & 0.603 & 1.377 & 1.244 & 1.883 & 0.966944147 & 0.044 \\
\hline 2.0 & 0.099 & 0.211 & 0.372 & 0.831 & 1.311 & 1.912 & 2.438 & 0.999314577 & 0.057 \\
\hline 2.5 & 0.104 & 0.174 & 0.392 & 0.821 & 1.293 & 1.934 & 2.178 & 0.993353935 & 0.094 \\
\hline
\end{tabular}

\section{Effect of masking agent:}

The effect of different amounts $0-5 \mathrm{ml}$ of $0.01 \mathrm{M}$ of various masking agents such as (EDTA, $\mathrm{NaF}, \mathrm{NTA}$, EGTA, CDTA) adjusted to $\mathrm{pH} 4.3$ on absorbance was studied. The results are shown in (Table 5).

Table 5: Effect of masking agents

\begin{tabular}{|c|c|c|c|c|c|c|c|}
\hline \multirow{2}{*}{ Masking agent } & \multicolumn{7}{|c|}{ Absorbance / $\mathrm{ml}$ of masking agent added } \\
\hline & 0.0 & 1.0 & 2.0 & 3.0 & 4.0 & 5.0 & $\lambda_{\max }$ \\
\hline EDTA* & \multirow{5}{*}{0.211} & 0.077 & 0.041 & 0.011 & 0.008 & 0.002 & 511 \\
\hline $\mathrm{NaF}$ & & 0.092 & 0.073 & 0.052 & 0.032 & 0.012 & 500 \\
\hline NTA** & & 0.111 & 0.101 & 0.092 & 0.072 & 0.055 & 512 \\
\hline EGTA*** & & 0.133 & 0.092 & 0.052 & 0.032 & 0.022 & 510 \\
\hline CDTA $^{* * * *}$ & & 0.123 & 0.117 & 0.097 & 0.058 & 0.040 & 509 \\
\hline
\end{tabular}

* EDTA $=$ Ethylendiamintetraacetic acid.

** NTA $=$ Nitrilotriacetic acid.

$* * *$ EGTA=Ethylenglycol-O,O-bis(2-aminoethyl)-N,N,N,N-tetraaceticacid.

$* * * *$ CDTA=Trans-1,2-diaminocyclohexane-N,N,N,N-tetraacetic acid monohydrate.

The results shown in (Table 5) indicate that the addition of masking agents solution give no useful results therefore it was ommited for the subsequent experiments.

\section{Effect of surfactants}

The presence of surfactants in a coloured complex solution was tested such as sodium dodecyl sulphate (SDS) (anionic surfactant), cetyltrimethylammonium bromide (CTAB), cetylpyridinium chloride(CPC) (cationic surfactants) and triton X-100(non-ionic surfactant). The results in (Table 6) indicate that the addition of surfactants give no useful effect on absorbance except triton X-100. Therefore, the amount of triton X-100 was studied as shown in Fig. (2).

Table 6: Effect of surfactant

\begin{tabular}{|l|c|c|c|c|c|}
\hline \multicolumn{1}{|c|}{ Surfactant } & \multicolumn{5}{c|}{ Absorbance / ml of surfactant added } \\
\cline { 2 - 6 } & 1.0 & 2.0 & 3.0 & 4.0 & 5.0 \\
\hline Cetyltrimethylammonium bromide & 0.178 & 0.128 & 0.121 & 0.082 & 0.006 \\
\hline Sodium dodecylsulphate & 0.189 & 0.112 & 0.053 & 0.022 & 0.007 \\
\hline Cetyl pyredinium chloride & 0.178 & 0.133 & 0.111 & 0.092 & 0.006 \\
\hline Triton X-100 & 0.194 & 0.219 & 0.214 & 0.217 & 0.215 \\
\hline Without surfactant & \multicolumn{5}{|c|}{0.210} \\
\hline
\end{tabular}




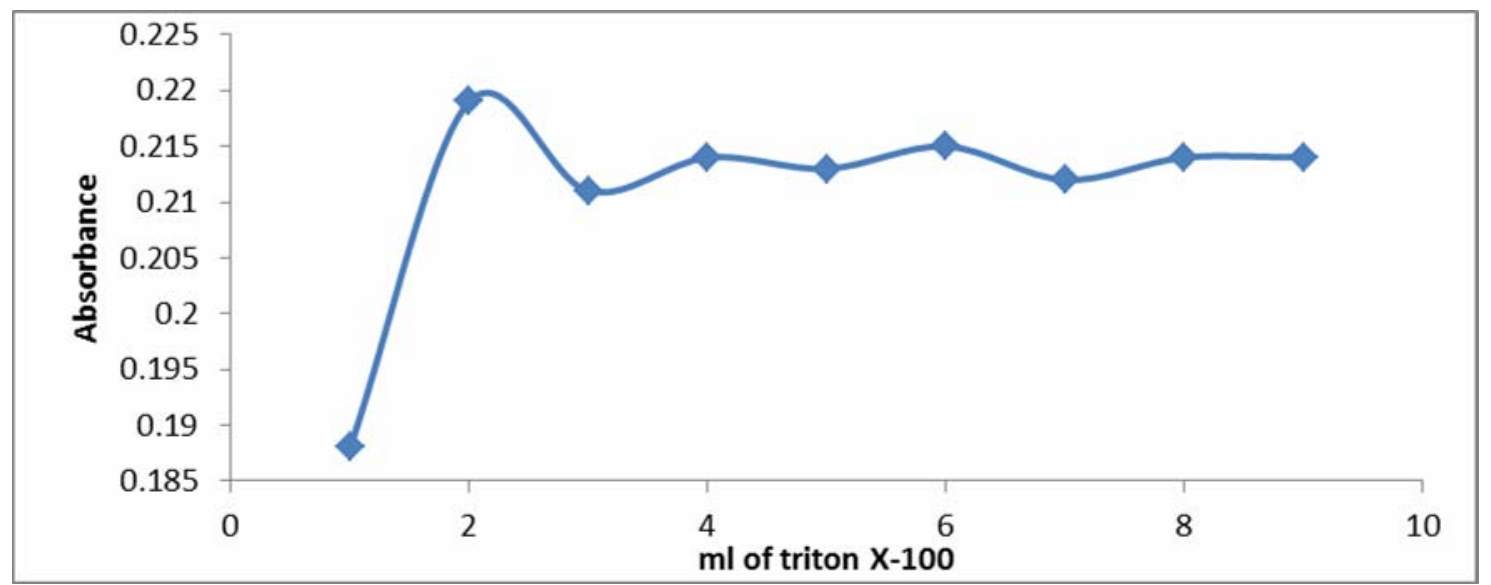

Fig. 2: Effect of amount of triton X-100

\section{Order of addition and stability of complex}

To the metal ion solution (M), each of buffer solution (B), and xylenol orange solution (R) added in possible orders. Experiments have showed that the order of addition $(M+B+R)$ gives the best absorbance. The addition of $2 \mathrm{ml}$ triton X-100 increases the reaction stability and decreases the absorbance of corresponding reagent blank, therefore the order $(\mathrm{M}+\mathrm{B}+\mathrm{T}+\mathrm{R})$ which gives the best absorbance was selected for subsequent experiments. The time for reaching maximum absorbance for the coloured complex was only 1 minute and the absorbance remains maximum and stable for at least 24 hours in the presence of triton X-100 and just 40 minutes in the absence of triton $\mathrm{x}-100$ Fig. (3).

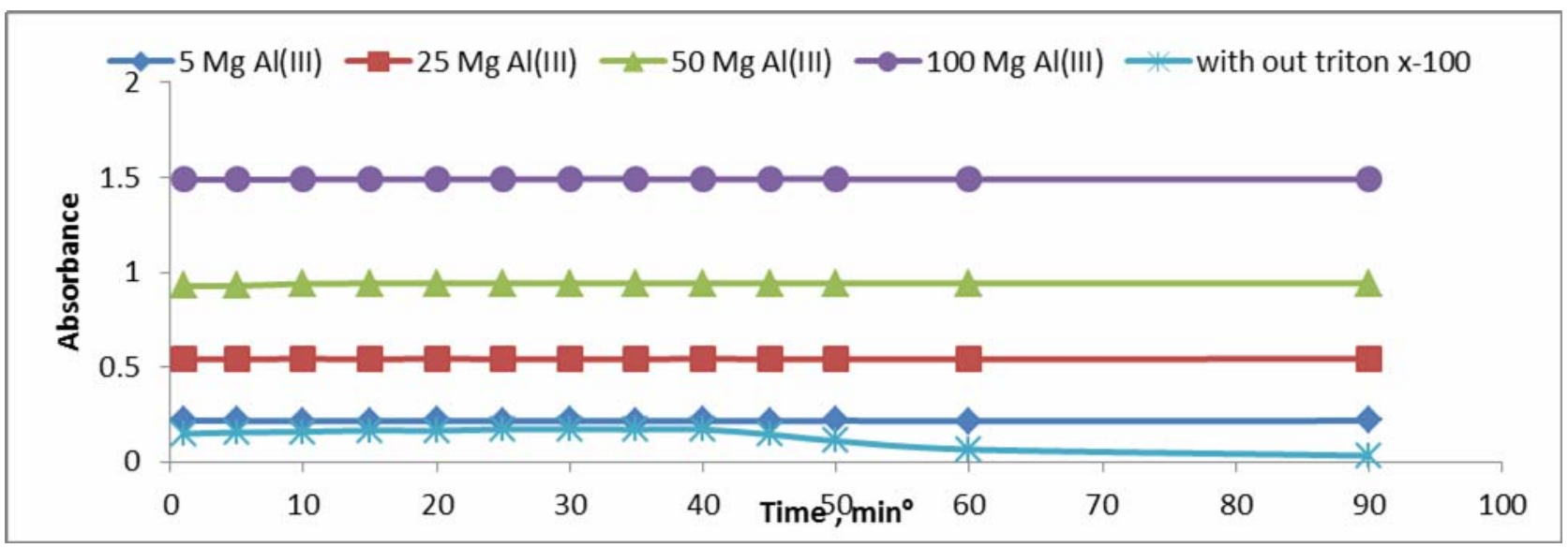

Fig. 3: Stability of complex

\section{Final Absorption Spectra}

Absorption spectra of the coloured complex aluminium-xylenol orange- triton $\mathrm{X}-100$ in the presence of $\mathrm{KH}$-phthalate buffer solution at $\mathrm{pH} 4.3$ against its corresponding reagent blank shows maximum absorption at $512 \mathrm{~nm}$ in contrast to the xylenol orange reagent blank Fig. (4). 


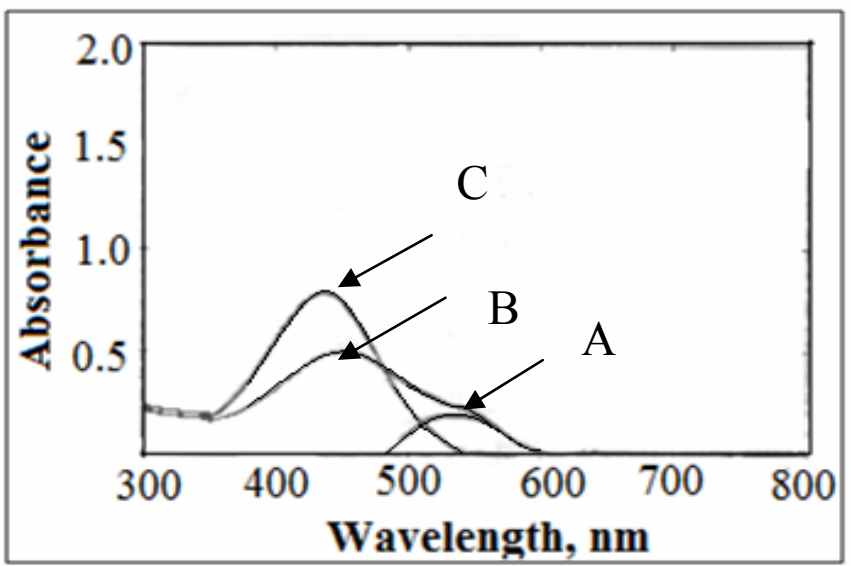

Fig. 4: Absorption spectra of $5 \mu \mathrm{g}$ of aluminium in the presence of triton $\mathrm{X}-100 / 25 \mathrm{ml}$ measured (A) against reagent blank (B) against distilled water, and(C) blank against distilled water.

\section{Accuracy and precision}

Under the experimental conditions which included in the recommended procedure, the recovery and precision of the method have been checked by performing five replicate determination for 5,50,100 $\mu \mathrm{g}$ of aluminium, the recovery and relative standard deviation are shown in (Table 7), indicating that the method has a good accuracy and precision.

Table 7 : Accuracy and precision

\begin{tabular}{|c|c|c|}
\hline Amount of aluminium taken, $\boldsymbol{\mu g} / \mathbf{2 5 m l}$ & Recovery*, $\%$ & Relative standard deviation*, $\%$ \\
\hline 5 & 99.63 & \pm 0.00083 \\
\hline 50 & 99.79 & \pm 0.0011 \\
\hline 100 & 99.91 & \pm 0.00084 \\
\hline
\end{tabular}

- Average of five determinations.

\section{Nature of the coloured complex}

Job's method of the continuous variations and mole ratio (Hauser, 2004) method under the established condition have been used to study the stoichiometry of the complex aluminium - xylenol orange reagent. The results in both methods Figs. (5 and 6) show that the molar ratio of $\mathrm{Al}^{+3}$ to $\mathrm{XO}$ in the complex was found to be 1:2.

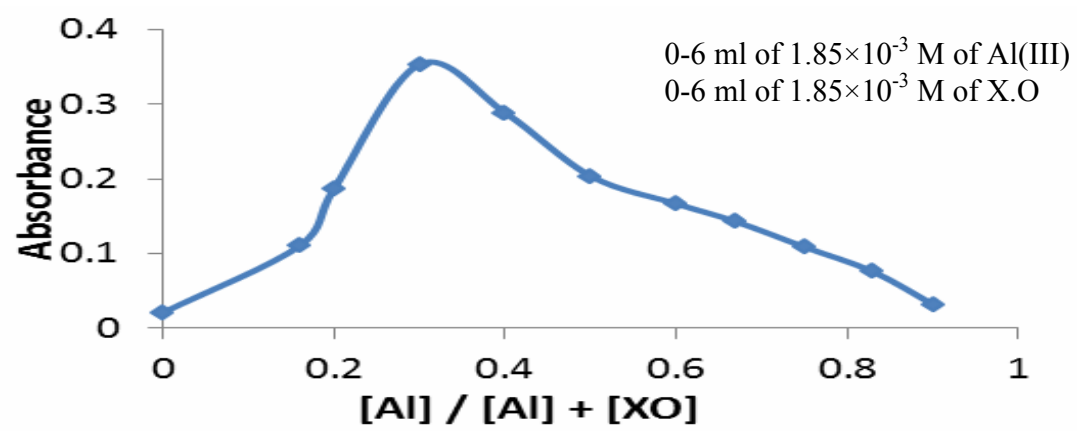

Fig.5: Job's plot for Al-XO 


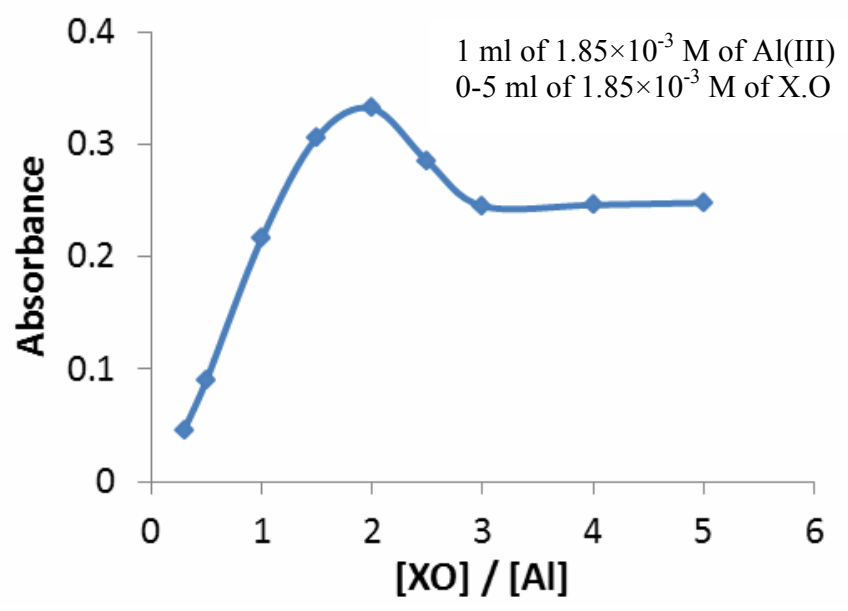

Fig. 6: Mole ratio's plot for Al-XO.

\section{Effect of foreign ions}

The effect of many foreign ions on the determination of $5 \mu \mathrm{g}$ aluminium per $25 \mathrm{ml}$ of solution was examined under the experimental conditions used. The results obtained were summarized in (Table 8).

\section{Table 8: Effect of foreign ions}

\begin{tabular}{|c|c|c|c|c|c|}
\hline \multirow{2}{*}{ Foreign ion } & \multirow{2}{*}{ Form added } & \multicolumn{4}{|c|}{ Interference \% } \\
\hline & & 50 & 100 & 250 & 500 \\
\hline $\mathrm{SO}_{3}^{-2}$ & $\mathrm{Na}_{2} \mathrm{SO}_{3}$ & -6.54 & -5.14 & -4.21 & -3.27 \\
\hline $\mathrm{NO}_{2}^{-}$ & $\mathrm{NaNO}_{2}$ & -0.92 & -0.88 & -0.97 & -1.07 \\
\hline $\mathrm{NO}_{3}^{-}$ & $\mathrm{NaNO}_{3}$ & -0.73 & -0.76 & -.085 & -0.83 \\
\hline $\mathrm{CO}_{3}{ }^{=}$ & $\mathrm{Na}_{2} \mathrm{CO}_{3}$ & -0.53 & -0.51 & -0.56 & -0.58 \\
\hline $\mathrm{S}_{2} \mathrm{O}_{3}{ }^{=}$ & $\mathrm{Na}_{2} \mathrm{~S}_{2} \mathrm{O}_{3} .5 \mathrm{H}_{2} \mathrm{O}$ & -0.99 & -1.07 & -1.22 & -1.37 \\
\hline $\mathrm{PO}_{4}^{-3}$ & $\mathrm{NaH}_{2} \mathrm{PO}_{4} \cdot 2 \mathrm{H}_{2} \mathrm{O}$ & -1.93 & -2.11 & -2.25 & -2.28 \\
\hline $\mathrm{Ca}^{+2}$ & $\mathrm{CaSO}_{4}$ & -0.41 & -0.41 & -0.43 & -0.43 \\
\hline $\mathrm{Mg}^{+2}$ & $\mathrm{Mg} \mathrm{SO}_{4} .7 \mathrm{H}_{2} \mathrm{O}$ & -0.55 & -0.57 & -0.59 & -0.59 \\
\hline $\mathrm{Li}^{+}$ & $\mathrm{Li}_{2} \mathrm{SO}_{4} \cdot \mathrm{H}_{2} \mathrm{O}$ & -0.82 & -0.94 & -1.08 & -1.31 \\
\hline $\mathrm{Fe}^{+3}$ & $\mathrm{Fe}\left(\mathrm{NO}_{3}\right)_{3} .5 \mathrm{H}_{2} \mathrm{O}$ & +42.65 & +56.87 & +71.56 & +84.36 \\
\hline $\mathrm{Fe}^{+2}$ & $\mathrm{FeSO}_{4} .7 \mathrm{H}_{2} \mathrm{O}$ & -2.14 & -2.19 & -2.25 & -2.28 \\
\hline $\mathrm{Co}^{+2}$ & $\mathrm{Co}\left(\mathrm{NO}_{3}\right)_{2} \cdot 6 \mathrm{H}_{2} \mathrm{O}$ & -1.82 & -1.88 & -1.89 & -1.91 \\
\hline $\mathrm{Hg}^{+2}$ & $\mathrm{Hg}\left(\mathrm{NO}_{3}\right)_{2} \cdot \mathrm{H}_{2} \mathrm{O}$ & -0.87 & -0.92 & -0.94 & -0.97 \\
\hline $\mathrm{Cd}^{+2}$ & $\mathrm{Cd}\left(\mathrm{CH}_{3} \mathrm{COO}\right)_{2} \cdot \mathrm{H}_{2} \mathrm{O}$ & -0.77 & -0.81 & -0.88 & -0.92 \\
\hline $\mathrm{Pb}^{+2}$ & $\mathrm{~Pb}\left(\mathrm{NO}_{3}\right)_{2}$ & -1.03 & -1.10 & -1.14 & -1.18 \\
\hline $\mathrm{Be}^{+2}$ & $\mathrm{BeSO}_{4} \cdot 4 \mathrm{H}_{2} \mathrm{O}$ & -1.93 & -4.25 & -9.33 & -17.81 \\
\hline $\mathrm{Cr}^{+3}$ & $\mathrm{CrCl}_{3} \cdot 6 \mathrm{H}_{2} \mathrm{O}$ & -0.86 & -0.93 & -0.99 & -0.98 \\
\hline $\mathrm{Ti}^{+}$ & $\mathrm{TiCl} 4$ & -2.06 & -2.33 & -2.59 & -2.98 \\
\hline $\mathrm{Si}^{+}$ & $\mathrm{Na}_{2} \mathrm{SiO}_{3} .5 \mathrm{H}_{2} \mathrm{O}$ & -1.26 & -1.33 & -1.49 & -1.68 \\
\hline $\mathrm{Ni}^{+2}$ & $\mathrm{NiCl}_{2} \cdot 6 \mathrm{H}_{2} \mathrm{O}$ & -0.59 & -0.77 & -0.91 & -1.10 \\
\hline $\mathrm{Mn}^{+2}$ & $\mathrm{MnCl}_{2} \cdot 4 \mathrm{H}_{2} \mathrm{O}$ & -0.15 & -0.32 & -0.50 & -0.65 \\
\hline $\mathrm{Cu}^{+2}$ & $\mathrm{CuSO}_{4}$ & -0.31 & -0.39 & -0.61 & -0.74 \\
\hline
\end{tabular}

The method seems to be moderately selective, except towards $\mathrm{Fe}^{+3}$, and $\mathrm{Be}^{+2}$ at high concentration. In case of the higher concentration of beryllium possess many properties similar to aluminium and its compounds (Hotzbecher et al., 1976).

\section{Determination of aluminium in the presence of iron (III):}

The proposed method was developed for determining aluminium in the presence of ferric ions choosing sodium cyanide as a suitable masking agent for ferric ion. The results are shown in (Table 9). 
Table 9: Effect of choosing the best masking agent for iron(III)

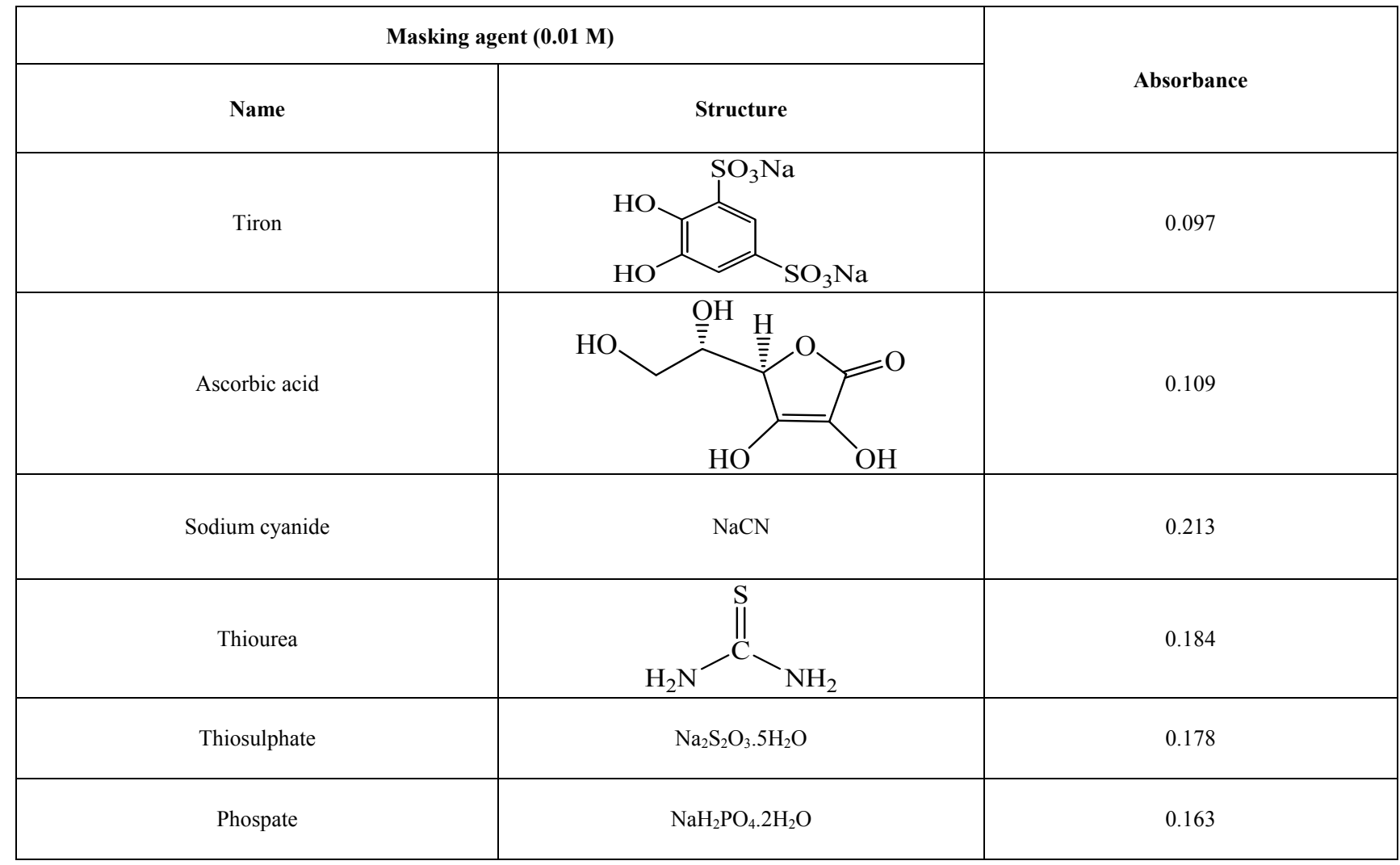

To mask the ferric ion, sodium cyanide was used as masking agent for this purpose. Therefore, different volumes $(1.0-3.0) \mathrm{ml}$ of $(0.01 \mathrm{M})$ sodium cyanide solution were added to a solution containing a mixture of $5 \mu \mathrm{g}$ aluminium and different amounts (10-500 $\mu \mathrm{g})$ of ferric ions then $3 \mathrm{ml}$ of buffer solution, $2 \mathrm{ml}$ of triton X-100 (1\%) and $2 \mathrm{ml}$ of $1 \times 10^{-3}$ xylenol orange. The results are given in (Table 10) indicate that $2 \mathrm{ml}$ of $0.01 \mathrm{M}$ sodium cyanide solution are suitable to prevent the interference caused by $\mathrm{Fe}^{3+}$ ions.

Table 10: Determination of aluminium in presence of iron(III)

\begin{tabular}{|c|c|c|c|c|c|c|}
\hline \multirow{2}{*}{$\mathrm{ml}$ of $\mathrm{NaCN} 0.01$ M solution } & \multicolumn{6}{|c|}{ Absorbance / $\mu \mathrm{g}$ of Fe(III) Present } \\
\hline & 10 & 50 & 100 & 200 & 300 & 500 \\
\hline 1.0 & 0.266 & 0.354 & 0.363 & 0.386 & 0.399 & 0.472 \\
\hline 1.5 & 0.243 & 0.264 & 0.289 & 0.310 & 0.344 & 0.374 \\
\hline 2.0 & 0.215 & 0.213 & 0.211 & 0.216 & 0.219 & 0.217 \\
\hline 2.5 & 0.199 & 0.198 & 0.210 & 0.216 & 0.227 & 0.233 \\
\hline 3.0 & 0.173 & 0.184 & 0.196 & 0.211 & 0.212 & 0.215 \\
\hline
\end{tabular}

\section{Application of the method}

The proposed method was applied to determine aluminium in various water samples. On applying procedure, good recovery is obtained as shown in (Table 11). 
Table 11: Determination of aluminium in various water samples

\begin{tabular}{|c|c|c|c|c|c|}
\hline \multirow{2}{*}{$\begin{array}{l}\text { ml of water } \\
\text { sample }\end{array}$} & \multirow{2}{*}{$\underset{\mu \mathrm{g}}{\text { Aluminium added, }}$} & \multicolumn{4}{|c|}{ Recovery $(\%)$ of aluminium } \\
\hline & & Tap water & Tigris water* & Sea water** & Well water*** \\
\hline 3 & \multirow{3}{*}{5} & 101.42 & 99.94 & 99.92 & 99.93 \\
\hline 5 & & 100.21 & 99.90 & 99.95 & 98.97 \\
\hline 7 & & 101.37 & 99.97 & 100.11 & 98.84 \\
\hline 3 & \multirow{3}{*}{50} & 101.89 & 99.96 & 101.10 & 100.91 \\
\hline 5 & & 99.94 & 100.04 & 100.28 & 101.42 \\
\hline 7 & & 99.89 & 100.01 & 100.34 & 101.63 \\
\hline 3 & \multirow{3}{*}{100} & 100.47 & 99.97 & 100.16 & 99.97 \\
\hline 5 & & 100.01 & 99.96 & 100.63 & 99.98 \\
\hline 7 & & 99.93 & 100.08 & 100.77 & 99.92 \\
\hline
\end{tabular}

*Tigris water in Mosul city/Iraq.

** Sea water from middle east sea in Turkey.

***Well water from al-Shurra village in Mosul/Iraq.

The performance of the proposed method was assessed by calculating the student $t$-test (Christian, 2004) with the literature method (Park and Cha, 2000; Eder et al., 2015). The results in (Table 11) show that the calculated " $t$ " values for five degrees of freedom (N1+N2-2) at the 95\% confidence level do not exceed the theoretical level $t$ value (2.571), indicating that there is no significant difference between the proposed method and the reported method.

Table 12: The value of " $t$ " test of natural waters

\begin{tabular}{|c|c|c|c|}
\hline \multirow{2}{*}{ Sample } & \multicolumn{2}{|c|}{ Recovery* (\%) } & \multirow{2}{*}{ "t" exp. } \\
\cline { 2 - 3 } & Present method & Reported method (Park and Cha, 2000) & \\
\hline Tap water & 100.01 & 100.32 & 0.0239 \\
\hline Sea water & 99.98 & 99.65 & 1.403 \\
\hline Tigris water & 100.53 & 99.98 & 0.1413 \\
\hline Well water & 99.93 & 99.91 & 1.236 \\
\hline
\end{tabular}

\section{Comparison of method}

(Table 13) shows the comparison of some analytical parameters for literatures spectrophotometric methods for Aluminum (III) determination with proposed method. It can be seen from (Table 13) that the proposed method is a moderately sensitive method for Aluminum determination. 
Table 13: Comparison of methods

\begin{tabular}{|c|c|c|c|c|}
\hline $\begin{array}{l}\text { Analytical } \\
\text { parameter }\end{array}$ & Present method & $\begin{array}{c}\text { Literature method } \\
\text { (Saritha and Reddy } \\
\text { 2014) }\end{array}$ & $\begin{array}{l}\text { Literature method (Eder } \\
\text { et al., 2015) }\end{array}$ & $\begin{array}{l}\text { Literature method } \\
\text { (Carpani et al., } \\
\text { 2004) } \\
\end{array}$ \\
\hline$\lambda_{\max }(\mathrm{nm})$ & 512 & 390 & 510 & 554 \\
\hline $\mathrm{pH}$ & 4.3 & $3.0-7.0$ & 4.5 & ----- \\
\hline Buffer & KH-phthalate & Sodium acetate-acetic acid & Sodium acetate-acetic acid & $\begin{array}{ll}---- \\
\end{array}$ \\
\hline Reagent & Xylenol orange & $\begin{array}{l}\text { 5-Bromo-2-hydroxy-3- } \\
\text { methoxy benzaldehyde-p- } \\
\text { hydroxybenzoic hydrazone }\end{array}$ & Alzarin red S & Xylenol orange \\
\hline Medium & Aqueous & Di methyl formamide & Aqueous & Aqueous \\
\hline Surfactant & triton $\mathrm{X}-100$ & ------ & Polyvinylpyrrolidone 40 & \\
\hline $\begin{array}{l}\text { Beer's law range } \\
\left(\mu \mathrm{g} \cdot \mathrm{ml}^{-1}\right)\end{array}$ & $0.04-8.0 \mu \mathrm{g} . \mathrm{ml}^{-1}$ & $0.053-0.755$ & $5.0-320$ & $0.14-1.8$ \\
\hline$\varepsilon\left(1 . \mathrm{mol}^{-1} . \mathrm{cm}^{-1}\right)$ & $1.173 \times 10^{4}$ & $2.66 \times 10^{4}$ & ------ & $2.45 \times 10^{4}$ \\
\hline $\begin{array}{l}\text { Sandell's sensitivity } \\
\left(\mu \mathrm{g} . \mathrm{cm}^{-2}\right)\end{array}$ & 0.00230 & 0.00104 & ------ & $1.1 \times 10^{-3}$ \\
\hline $\mathrm{RSD}, \%$ & $\begin{array}{c} \pm 0.0011 \text { to } \pm \\
0.00084\end{array}$ & 0.0075 & $4 \%$ & ----- \\
\hline Interference & $\mathrm{Fe}^{+3}$ & $\mathrm{Ni}^{+2}, \mathrm{Fe}^{+3}, \mathrm{Cu}^{+2}, \mathrm{Ti}^{+4}$ & $\mathrm{Fe}^{+3}, \mathrm{Ca}^{+2}$ & ----- \\
\hline Masking agent & Sodium cyanide & Iodide and EDTA & $\begin{array}{l}\text { Ascorbic acid for } \mathrm{Fe}^{+3} \\
\text { L-Histidine for } \mathrm{Ca}^{+2}\end{array}$ & ----- \\
\hline $\begin{array}{l}\text { Application of } \\
\text { method }\end{array}$ & $\begin{array}{c}\text { Sea water, Tigris } \\
\text { water, } \\
\text { Well water and Tap } \\
\text { water }\end{array}$ & $\begin{array}{l}\text { silicate minerals, industrial } \\
\text { sludges, soil samples plant } \\
\text { extracts, hair, tea and } \\
\text { water samples. }\end{array}$ & Hemodialysis water & $\begin{array}{l}\text { synthetic samples } \\
\text { of hydrotalcite }\end{array}$ \\
\hline
\end{tabular}

\section{CONCLUSION}

The development of simple, sensitive, moderately selective and inexpensive spectrophotometric method for the determination of Aluminum in different water samples has been carried out, using xylenol orange reagent. The complex formed was stable, water soluble and has a maximum absorption at $512 \mathrm{~nm}$ with molar absorptivity of $1.173 \times 10^{4} 1 . \mathrm{mol}^{-1} . \mathrm{cm}^{-1}$ and Sandall's sensitivity of $0.00230 \mu \mathrm{g} . \mathrm{cm}^{-2}$ in presence of triton X-100 while the values of molar absorptivity and Sandell's sensitivity $1.045 \times 10^{4} 1 . \mathrm{mol}^{-1} . \mathrm{cm}^{-1}, 0.00258 \mu \mathrm{g} . \mathrm{cm}^{-2}$ respectively in absence of triton $\mathrm{X}-100$.

The inteferred of iron (III) ions can be removed by adding $0.01 \mathrm{M}$ sodium cyanide as a masking agent, Beer's law is obeyed in the concentration range from 0.04-8.0 $\mu \mathrm{g} / \mathrm{ml}$ (in presence of triton X-100) and $0.2-4.0 \mu \mathrm{g} / \mathrm{ml}$ (in absence of titon X-100) of Aluminum. The proposed method has been applied successfully to the determination of Aluminum in different water samples.

\section{REFERENCES}

Al-Kindy, S.; Al-Hinai, A.; Al-Rasbi, N.; Eldin, O.; Al-Lawati, S. (2015). Spectrofluorimetric determination of aluminium in water samples using N-((2-hydroxynaphthalen-1-yl)methylene) acetylhydrazide. JTUSCI J. Taibah University for Science, 9(4), 601-609.

Andrade, J.; Coscione, A.; Poppi, R.; Mello, C. (2008). Elimination of iron interference in the molecular spectrophotometric determination of aluminum in soil extracts using artificial neural networks. Anal. Sci., 24, 1147-1150.

Carpani, I.; Scavetta, E.; Tonelli, D. (2004). Spectrophotometric determination of Aluminum and nickel. Ann. Chim. , 94(5-6), 365-72.

Christian, G.D. (2004). "Analytical Chemistry". John Wiley and Sons , USA, $6^{\text {th }}$ ed., pp. 83-99.

Darbre, P.D. (2016). Aluminum and the human breast. Morphologie, 100(329), 65-74.

Devoret, M.; Schoelkopf, R. (2013). Superconducting circuits for quantum Information: An outlook. Science, 339(6124), 1169-1174.

Eder, J.; Eduardo, B.; Ronei, E.; Amanda, B.; Ralph, E. (2015). Spectrophotometric determination of Aluminum in hemodialysis water. J. Braz. Chem. Soc., 26(11), 2384-2388. 
Exley, C. (2016). The toxicity of Aluminum in humans, Morphologie, 100(329), 51-55.

Exley, C. (2013). Human exposure to Aluminum. Environ. Sci., Processes and Impacts,.15 (10),1807-1816.

Hauser, A. (2004). Ligand field theoretical considerations. Adv. Polym. Sci., 233, 49-58.

Heena, K.R.; Rani, S.; Malik, A. (2015). Development of a rapid and sensitive method for the determination of Aluminum by reverse-phase high-performance liquid chromatography using a fluorescence detector. J. Chromatog. Sci., 53, 800-806.

Hotzbecher, Z.; Divis, L.; Kral, M.; Sucha, L.; Vlacil, F. (1976). "Hand Book of Organic Reagent in Inorganic Analysis. Ellis Horwood, Ltd., Chichester. pp. 453, 459, 465.

Jamaluddin, A.; Reazul, H.; Shahed, H.; Bhattacharjee, S. (2010). A Simple spectrophotometric method for the determination of aluminum in some real, environmental, biological, soil and pharmaceutical samples using 2-hydroxynaphthaldehydebenzoylhydrazone. Eurasian J. Anal. Chem ., 5(1),1-15.

Khanhuathon, Y.; Siriangkhawut, W.; Chantiratikul, P.; Grudpan, K. (2015). Spectrophotometric method for determination of Aluminum content in water and beverage samples employing flow-batch sequential injection system. J. Food Composition and Analysis, 41, 45-53.

Kobra, Z.; Morteza, A.; Mahnaz, S. (2007). Simultaneous spectrophotometric determination of aluminum and Iron in micellar media by using the H-point standard addition method. J. Chinese Chem. Soc., 54, 1395-1400.

Kufman, J. (2000). "Introduction to Alloys and Tempers". ASM International, $1^{\text {st }}$ ed., U.S.A., pp. 5, 10, 16.

Marczenko, Z. (2000). "Spectrophotometric Determination of Elements". Ellis Horwood Ltd., Chichester, pp. 114-120.

Meija, J.; Coplen, T.; Berglund, M.; Brand, W.; De Bièvre, P.; Gröning, M.; Holden, N.E.; Irrgeher, J.; Loss, R.; Walczyk, T.; Prohaska, T. (2016). Atomic weights of the elements 2013,IUPAC Technical Report) . Pure Appl. Chem., 88(3), 265-291.

Ni, Y.; Huang, C.; Kokot, S. (2007). Simultaneous determination of iron and aluminium by differential kinetic spectrophotometric method and chemometrics. Anal. Chim. Acta., 599(2), 209-218.

Panhwar, A.; Tuzen, M.; GulKazi, T. (2018). Deep eutectic solvent based advance microextraction method for determination of aluminum in water and food samples: Multivariate study. Talanta, 178, 588593.

Park, C.; Cha, K. (2000). Spectrofluorimetric method for determination of Aluminum with chromo tropic acid and its application to water samples, Talanta, 51, 769-774.

Pogue, A.; Lukiw, W. (2016). Aluminum, the genetic apparatus of the human CNS and Alzheimer's disease (AD). Morphologie, 100 (329), 56-64.

Purrin, D.; Dempsey, B. (1974). "Buffers for pH and Metal Ion Control". Chapman and Hall, Ltd., 130-136.

Rana, S.; Mittal, S.; Singh, N.; Singh, J.; Banks, C. (2017). Schiff base modified screen printed electrode for selective determination of Aluminum (III) at trace level. Sensors and Actuators B: Chemical, 239, $17-27$.

Santarossa, D.; Talio, M.; Fernández, L. (2016). Aluminum traces determination in biological and water samples using a novel extraction scheme combined with molecular fluorescence, Microchem. J., 129, 274-280

Saritha, B.; Reddy, T. (2014). Direct spectrophotometric determination of aluminum (III) using 5-bromo-2hydroxy-3-methoxybenzaldehyde-phydroxybenzoic hydrazone. IOSR J. Appl. Chem., 7(2), 5-10.

Shishov, A.; Bulatov, A.; Moskvin, A.; Moskvin, L. (2014). Simultaneous cyclic-injection spectrophotometric determination of aluminum and iron in petroleum products. J. Anal. Chem., 69(12), 1159-1164.

Siriangkhawut, W.; Tontrong, S.; Chantiratikul, P. (2013). Quantization of Aluminum content in waters and soft drinks by spectrophotometry using eriochrome cyanine R. Research J. Pharm., Biol. and Chem. Sci., 4(3), 1155-1161.

Snell, F. (1978). "Photometric and Fluorimetric Method of Analysis Metals." John Wiley and Sons, Inc., New York, pp. 272-1062.

Ulusoy, H.; Gürkan, R.; Aksoy, Ü.; Akçay, M. (2011). Development of a cloud point extraction and preconcentration method for determination of trace aluminum in mineral waters by FAAS. Microchem. J., 99(1), 76-81. 